\title{
Genetic characterization of Porcine Circovirus 2 found in Malaysia
}

Seetha Jaganathan ${ }^{1,3^{*}}$, Ooi P Toung ${ }^{1}$, Phang L Yee ${ }^{2}$, Tan D Yew ${ }^{3}$, Choo P Yoon ${ }^{4}$ and Lim B Keong ${ }^{4}$

\begin{abstract}
Background: Porcine circovirus type 2 is the primary etiological agent associated with a group of complex multifactorial diseases classified as Porcine Circovirus Associated Diseases (PCVAD). Sporadic cases reported in Malaysia in 2007 caused major economic losses to the 2.2 billion Malaysian ringgit (MYR) (approximately 0.7 billion US dollar) swine industry. The objective of the present study was to determine the association between the presence of PCV2 and occurrences of PCVAD.

Results: This study showed that 37 out of 42 farms sampled were positive for PCV2 using PCR screening. Thirteen whole genome of PCV2 isolates from pigs with typical PCVAD symptoms were successfully sequenced. These isolates shared $98.3-99.2 \%$ similarities with sequences of isolates from the Netherlands. All thirteen isolates fell into the same clade as PCV2b isolates from other countries. Amino acid sequence analysis of the putative capsid protein (ORF2) of the PCV2 revealed that there are three clusters found in Malaysia, namely cluster 1C and 1A/1B. Of interest, three of the isolates (isolates Mal 005, Mal 006 and Mal 010) had a proline substitution for arginine or isoleucine encoded at nt. position 88-89. Eight of the isolates had mutations at the $\mathrm{C}$ terminus of the putative capsid protein suggestive of higher pathogenicity which may account for the high reports of PCVAD clinical symptoms in 2007.

Conclusion: Phylogenetic study suggests that there may be a link between movements of animals by import of breeders into the country being the route of entry of the virus. While it is not possible to eradicate the virus from commercial pigs, the swine industry in Malaysia can be safeguarded by control measures implemented throughout the country. These measures should include improved biosecurity, disease surveillance; vaccination as well as enforcement of regulations formulated to control and prevent the spread of this disease on a national scale.
\end{abstract}

Keywords: PCV2, PCVAD, phylogenetic

\section{Background}

Porcine circovirus (PCV) is a small non-enveloped DNA virus with a single-stranded circular DNA and a genome of about $1.76 \mathrm{kbp}$, making it the smallest autonomously replicating virus [1-6]. Porcine circovirus was first isolated as a non-cytopathic contaminant of the porcine kidney cell line PK15 in 1974 [7-9] and since then has been associated with many diseases related to swine. There are several genotypes of PCV. The most commonly reported genotypes are PCV1 and PCV2 [10-12]. However, a new PCV genotype was recently documented in Canada which contains the ORF1 of PCV1 and

\footnotetext{
* Correspondence: seetha_jeganathan@yahoo.com

'Department of Clinical Studies, Faculty of Veterinary Medicine, Universiti

Putra Malaysia, 43400 UPM, Serdang, Selangor, Malaysia

Full list of author information is available at the end of the article
}

the ORF2 of PCV2a. This new genotype which was assigned PCV1/2a has so far only been reported in Canada [13]. Within the PCV2 genotype, there are several sub-types (PCV2a-2e). PCV2c has been reported in pigs from Denmark [14], PCV2d are dominant in pigs from China [15] and PCV2e are found in pigs from Thailand [16]. Although PCV1 and PCV2 show high levels of nucleotide similarity, PCV1 is considered nonpathogenic whilst PCV2 has been reported as pathogenic and has been identified as the causative agent of PCV-associated diseases (PCVAD) or sometimes also referred to as postweaning multisystemic wasting syndrome (PMWS), a term used to describe all PCV2-associated clinical and subclinical manifestations [17-23]. Genetic characterizations based on the sequences that encode the putative capsid protein, (ORF2) has also

\section{Ciomed Central}


identified 2 groups of PCV2 genome with a total of eight clusters (1A to $1 \mathrm{C}$ and $2 \mathrm{~A}$ to $2 \mathrm{E}$ ) $[11,24,25]$. Group 1 has the sequence CCCCG/TC which encodes for proline and arginine/leucine (PR/PL) at nt. position 88-89, while group 2 has the sequence AAAATC which encodes for lysine and isoleucine (KI) at nt. position 8889 [26]. It is generally understood and accepted that group 1 represents PCV2b whilst group 2 represents PCV2a. Olvera et al. [26] reported genomes belonging to cluster $1 \mathrm{~B}$ could be the product of a recombinant event between a genome of cluster $1 \mathrm{~A}$ as the major parent and a genome of group 2 (most probably belonging to cluster 2D) as the minor parent [26] with PCV2b being the most prevalent form displaying highest pathogenicity compared to other genotypes [27]. Mutations have also been reported in many PCV2 strains worldwide including elongations in the putative capsid protein as a result of a single lysine $(\mathrm{K})$ residue deletions at the $\mathrm{C}$-terminus of the putative capsid protein in the stop codon of the open reading frame 2 (ORF2) $[15,24,26,28]$. This could account for the variations in the PCV2 findings reported worldwide in particular, the recent PCV2 studies where several new genotypes have been reported in Canada [13], Denmark [14], China [15] and Thailand [16]. Overall, both genotypes share less than $80 \%$ nucleotide sequence homology and approximately $75 \%$ homology at the amino-acid level [5,22,25,29-32].

In Malaysia, PCV2 was first identified by the Veterinary Research Institute in 2004 using RFLP methods followed by the first case study of PCVAD in 2007 based on clinical features, histopathology findings and PCR screening [33]. Globally, the virus has been reported in pigs in Canada and the United States, several European countries and some countries in Asia and can be considered as one of the most economically important emerging swine pathogens [14,15,19,26,34-38]. Realizing the impact it has on the swine industry in Malaysia which is worth over 2.2 billion ringgit, there is a need to understand the genetic characteristics of PCV2 to monitor its distribution. By understanding the genetic presence of PCV2 and its relationship to PCVAD, veterinary practitioners may be able to develop better vaccination programs against the disease. Currently, there are very few publications about PCV2 in this country. This study represents the complete genetic characterization and phylogenetic analysis of PCV2 reported for the first time in Malaysia.

42 pig farms were screened for PCV1 and PCV2. Thirteen positive samples from pigs with confirmed PCV2 were genetically characterized. These samples were from different states in Malaysia. Genetic variation among isolates from this study and PCV2 sequences from other countries deposited in Genbank were analyzed and compared.

\section{Results}

The detection of PCV1 and PCV2 from the Malaysian pig herd

Samples were collected from animals with typical clinical signs of PCVAD which include enlarged lymph nodes, wasting, dyspnea, pallor, severe weight loss and jaundice [37]. Samples tested positive for PCV1 were not used for further analysis. Initial investigations revealed that 37 out of the 42 farms were positive for PCV2 by conventional PCR.

\section{Genetic characterization, amino acid sequence analysis and phylogenetic study of the PCV2 isolates in Malaysia} A preliminary BLAST analysis confirmed that all 13 isolates were PCV2. As reported previously, the PCV genomic sequences ranged from 1758 to 1768 bp $[25,38]$. Assembly of the complete genomes of all 13 PCV2 isolates showed that all isolates from this study were 1767 bp in length. To confirm that all isolates from this study have the unique $N c o$ I restriction enzyme site that exist only in PCV2 [10,38] bioinformatics analysis was employed to map the restriction enzyme sites present in the complete genome. Our analysis confirmed that this unique feature was present in all the complete genomes isolated in this study at nucleotide position 668 to 673 (Figure 1). Phylogenetic analysis showed that all 13 isolates used for genetic characterization formed a group with other PCV2b isolates. Amino acid sequence analysis showed 3 distinct clusters; cluster $1 \mathrm{C}$ and cluster $1 \mathrm{~A} / 1 \mathrm{~B}$.

\section{Discussion}

Based on the 2010 data provided by the Department of Veterinary Services (DVS) on their website, there are approximately 565 pig farms in Malaysia. There are a total of 14 states in Malaysia. The 3 states of Kelantan, Terengganu and Pahang do not have any pig farms whilst the states of Pahang, Perlis and Negeri Sembilan have only 1 pig farm each and Kedah has only 2 pig farms. Therefore, samples in this study were collected from 6 states with big farms that are key players in the swine industry to represent the big picture of PCV2 distribution in Malaysia with the aim of characterizing the PCV2.

To determine the genetic differences among the PCV2 isolates found in Malaysia, the complete genome of PCV2 isolates from thirteen pigs exhibiting PCVAD symptoms in six states was amplified and sequenced. This included three pigs from Selangor (isolate Mal 003/11, Mal004/11, Mal 011/11), three pigs from Melaka (isolate Mal 001/11, Mal 002/11, Mal 008/11), three pigs from Penang (isolate Mal 005/11, Mal 007/11, Mal 013/ 11), two pigs from Sarawak (isolate Mal 006/11, Mal 009/11), one pig from Perak (isolate Mal 010/11) and finally one pig from Johor (isolate Mal 012/11). All the 


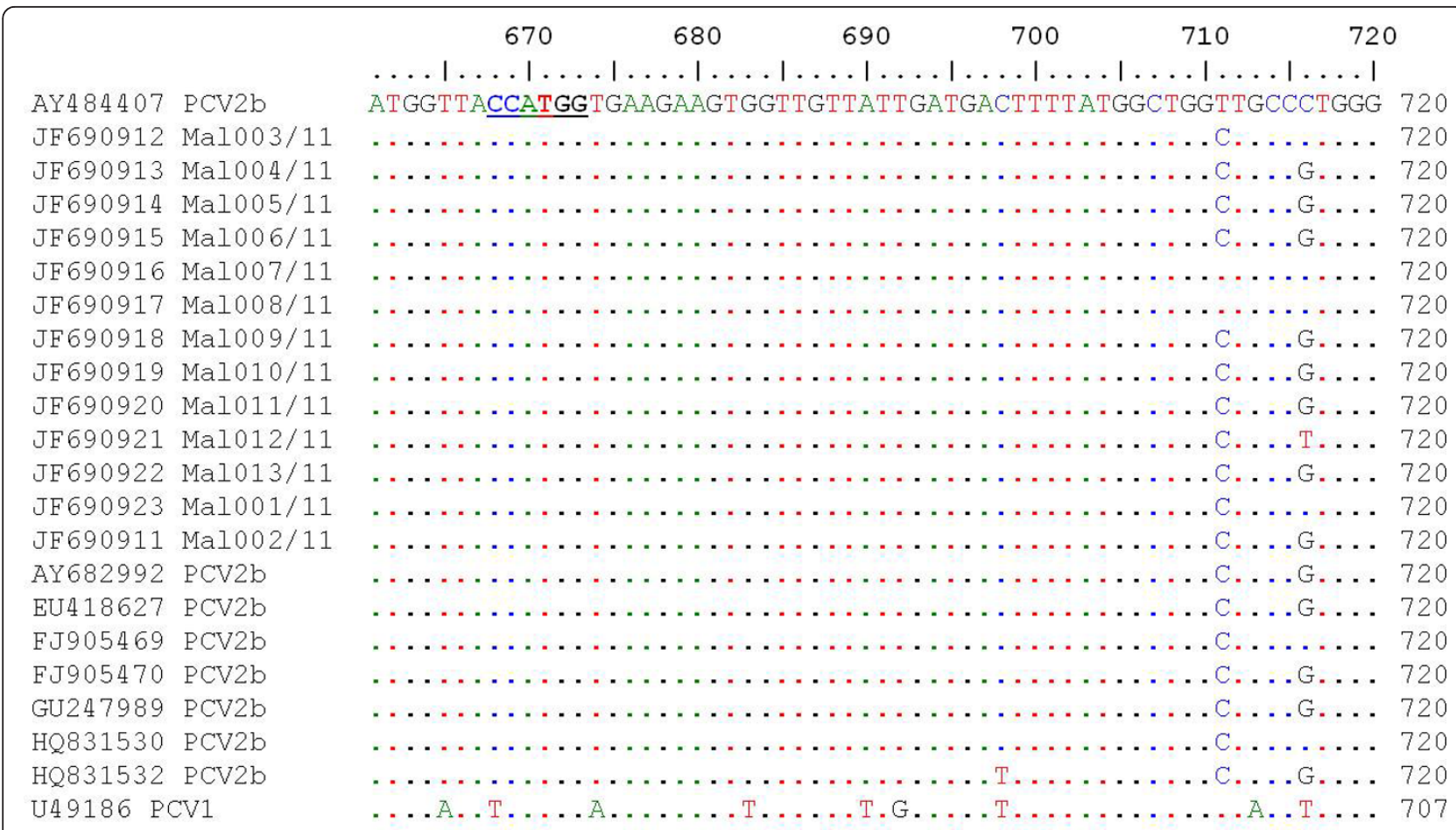

Figure 1 Nucleotide sequence alignment of a fragment of the complete genome of PCV1 and PCV2 found in this study. Alignments were performed using ClustalW. The unique Ncol restriction enzyme site that is present in all PCV2 [10] isolates is underlined.

PCV2 isolates sequenced were closely related to each other displaying between 97-99\% nucleotide sequence identity. When compared with other sequences from Genbank (Table 1), all thirteen isolates had closest relationship to isolate AY484407 from Netherlands with nucleotide sequence identity score ranging from 98.399.2\% (Table 2). The sequences in Table 1 were selected to represent the various subtypes and also to investigate the possible connection between countries of origin from which Malaysia imports the breeder pigs.

Numerous research has been carried out on PCV2 since it is considered to be pathogenic of the two genotypes identified. Amino acid sequence analysis showed that isolates from this study had three distinct clusters. The three clusters were cluster $1 \mathrm{C}$ and cluster $1 \mathrm{~A} / 1 \mathrm{~B}$. Interestingly, 3 of the isolates (isolate Mal 005, Mal006, Mal 010) had a proline (P) encoded at nt. position 89, substituting arginine/leucine $(\mathrm{R} / \mathrm{L})$. This mutation pattern has not been reported in other papers. Previous studies have documented that the ORF2 of PCV which codes for the putative capsid protein [28] encodes a protein of 233 amino acid residues. An amino acid sequence comparison revealed that the ORF2 genes of all 13 isolates shared $94.0-100 \%$ amino acid sequence identity. One PCV1 (U49816) and 3 PCV1/2a (FJ655419, FJ790425, FJ655418) nucleotide sequence from Genbank was included in this study as out groups. Previous studies have reported that there exist about $63-68 \%$ amino acid sequence identity between the ORF2 genes of PCV1 and PCV2 and similarly it was observed that all 13 PCV2 isolates from this study had 65-68\% amino acid similarities with the PCV1 (U49816) sequence downloaded from Genbank. All isolates showed about 90-95\% sequence similarities with the PCV1/2a sequences (Data not shown). Eight of the isolates (Mal 001/11, Mal 002/11, Mal 003/11, Mal 004/11, Mal 005/ 11, Mal 006/11, Mal 012/11, Mal013/11) displayed an elongation by one lysine $(\mathrm{K})$ residue at the $\mathrm{C}$-terminus of the putative capsid protein in a mutation at the stop codon of the ORF2 (Figure 2).

Phylogenetic analysis confirmed that all thirteen PCV2 isolates in this study grouped together and formed one distinct group with other PCV2b isolates. Likewise, all the PCV2a isolates which are closely related formed another group, while all the PCV1/2a, PCV2c and PCV2d isolates formed their own groups (Figure 3 ).

Neighboring countries such as Thailand [16] and Indonesia [19] have reported the presence of PCV2b cluster $1 \mathrm{C}$ and $\mathrm{PCV} 2 \mathrm{~b}$ cluster $1 \mathrm{~A} / \mathrm{B}$ respectively suggesting that similar PCV2b clusters as reported in this study are circulating in these few Asian countries in this region. This may also suggest that the swine in this region could be harboring the virus from the same source. 
Table 1 PCV2 isolates used in this study and other isolates reported previously

\begin{tabular}{|c|c|c|c|}
\hline Genotype & Name & Geographic Location & Reference or source \\
\hline \multirow[t]{13}{*}{ PCV2b } & Mal 001-JF690923 & Malaysia & This study \\
\hline & Mal 002-JF690911 & Malaysia & This study \\
\hline & Mal 003-JF690912 & Malaysia & This study \\
\hline & Mal 004-JF690913 & Malaysia & This study \\
\hline & Mal 005-JF690914 & Malaysia & This study \\
\hline & Mal 006-JF690915 & Malaysia & This study \\
\hline & Mal 007-JF690916 & Malaysia & This study \\
\hline & Mal 008-JF690917 & Malaysia & This study \\
\hline & Mal 009-JF690918 & Malaysia & This study \\
\hline & Mal 010-JF690919 & Malaysia & This study \\
\hline & Mal 011-JF690920 & Malaysia & This study \\
\hline & Mal 012-JF690921 & Malaysia & This study \\
\hline & Mal 013-JF690922 & Malaysia & This study \\
\hline PCV1 & U49186 & Ireland & Genbank \\
\hline \multirow[t]{3}{*}{ PCV1/2a } & FJ655419 & Canada & Genbank \\
\hline & FJ790425 & Canada & Genbank \\
\hline & FJ655418 & Canada & Genbank \\
\hline \multirow[t]{9}{*}{ PCV2a } & DQ629113 & USA & Genbank \\
\hline & DQ629114 & USA & Genbank \\
\hline & AF454546 & Korea & Genbank \\
\hline & AF408635 & Canada & Genbank \\
\hline & AB072301 & Japan & Genbank \\
\hline & AF520783 & Korea & Genbank \\
\hline & AF264038 & USA & Genbank \\
\hline & AY181948 & China & Genbank \\
\hline & AF465211 & Taiwan & Genbank \\
\hline \multirow[t]{9}{*}{$P C V 2 b$} & AY484407 & Netherlands & Genbank \\
\hline & HQ831530 & Portugal & Genbank \\
\hline & FJ905469 & Korea & Genbank \\
\hline & HQ831532 & Portugal & Genbank \\
\hline & EU418627 & China & Genbank \\
\hline & GU247989 & China & Genbank \\
\hline & FJ905470 & Korea & Genbank \\
\hline & AY682992 & China & Genbank \\
\hline & AY691169 & China & Genbank \\
\hline \multirow[t]{3}{*}{ PCV2C } & EU148503 & Denmark & Genbank \\
\hline & EU148504 & Denmark & Genbank \\
\hline & EU148505 & Denmark & Genbank \\
\hline \multirow[t]{9}{*}{ PCV2d } & EF524539 & China & Genbank \\
\hline & EF675241 & China & Genbank \\
\hline & AY181946 & China & Genbank \\
\hline & AY510375 & China & Genbank \\
\hline & AY181947 & China & Genbank \\
\hline & FJ158607 & China & Genbank \\
\hline & AY713470 & Germany & Genbank \\
\hline & DQ151643 & China & Genbank \\
\hline & DQ322701 & China & Genbank \\
\hline
\end{tabular}


Table 2 Sequence identity matrix of the capsid protein (ORF2) and the nucleotide alignment of the whole genome of the PCV2 isolates found in Malaysia

\begin{tabular}{|c|c|c|c|c|c|c|c|c|c|c|c|c|c|c|c|c|c|c|c|c|c|c|}
\hline Sequences & 1 & 2 & 3 & 4 & 5 & 6 & 7 & 8 & 9 & 10 & 11 & 12 & 13 & 14 & 15 & 16 & 17 & 18 & 19 & 20 & 21 & 22 \\
\hline (1) AY484407 PCV2b & & 98.4 & 98.6 & 98.4 & 98.6 & 99.2 & 99.3 & 98.4 & 99.1 & 99 & 98.3 & 98.4 & 98.6 & 98.3 & 99.5 & 99.5 & 99.2 & 99.2 & 99.6 & 99.7 & 99.5 & 76.2 \\
\hline $\begin{array}{l}\text { (2) JF690912 Mal003/ } \\
11\end{array}$ & 98.7 & & 99.6 & 99.7 & 99.5 & 97.7 & 98 & 97.5 & 98.9 & 98.9 & 99.5 & 99.7 & 99.6 & 99.4 & 98 & 98.1 & 98 & 97.9 & 98.3 & 98.2 & 98.1 & 76.5 \\
\hline $\begin{array}{l}\text { (3) JF690913 Mal004/ } \\
11\end{array}$ & 98.7 & 98.7 & & 99.6 & 99.9 & 97.9 & 98.3 & 97.9 & 99.3 & 99.3 & 99.6 & 99.7 & 99.7 & 99.4 & 98.4 & 98.5 & 98.3 & 98.3 & 98.6 & 98.4 & 98.5 & 76.4 \\
\hline $\begin{array}{c}\text { (4) JF690914 Mal005/ } \\
11\end{array}$ & 96.5 & 96.1 & 96.5 & & 99.7 & 97.7 & 98 & 97.6 & 99.1 & 99 & 99.6 & 99.7 & 99.6 & 99.5 & 98.1 & 98.3 & 98 & 98 & 98.4 & 98.2 & 98.3 & 76.3 \\
\hline $\begin{array}{c}\text { (5) JF690915 Mal006/ } \\
11\end{array}$ & 97.4 & 96.9 & 96.9 & 94.8 & & 97.9 & 98.3 & 97.9 & 99.4 & 99.2 & 99.5 & 99.6 & 99.7 & 99.4 & 98.4 & 98.5 & 98.3 & 98.3 & 98.6 & 98.4 & 98.5 & 76.3 \\
\hline $\begin{array}{c}\text { (6) JF690916 Mal007/ } \\
11\end{array}$ & 96.5 & 96.1 & 96.1 & 94 & 99.1 & & 98.8 & 97.9 & 98.4 & 98.4 & 97.6 & 97.7 & 98 & 97.6 & 98.7 & 98.7 & 98.4 & 98.4 & 98.8 & 98.9 & 98.7 & 75.5 \\
\hline $\begin{array}{c}\text { (7) JF690917 Mal008/ } \\
11\end{array}$ & 96.1 & 95.7 & 95.7 & 93.5 & 98.7 & 99.5 & & 98.1 & 98.8 & 98.7 & 98 & 98 & 98.3 & 97.9 & 98.9 & 98.9 & 98.5 & 98.6 & 99 & 99 & 98.8 & 76 \\
\hline $\begin{array}{c}\text { (8) JF690918 Mal009/ } \\
11\end{array}$ & 96.5 & 96.1 & 96.1 & 94 & 98.7 & 99.5 & 99.1 & & 98.4 & 98.3 & 97.5 & 97.6 & 97.8 & 97.5 & 98.3 & 98.4 & 97.7 & 98.1 & 98.5 & 98.3 & 98.2 & 75.4 \\
\hline $\begin{array}{l}\text { (9) JF690919 Mal010/ } \\
11\end{array}$ & 95.7 & 95.2 & 95.2 & 93.1 & 97.8 & 98.7 & 99.1 & 99.1 & & 99.8 & 98.9 & 99 & 99.2 & 98.9 & 98.9 & 99 & 98.5 & 98.8 & 99.1 & 98.9 & 99 & 76.4 \\
\hline $\begin{array}{l}\text { (10) JF690920 } \\
\text { Mal011/11 }\end{array}$ & 97.4 & 96.9 & 96.9 & 94.8 & 99.5 & 98.7 & 98.2 & 99.1 & 98.2 & & 99.1 & 99.1 & 99.3 & 99 & 98.8 & 98.9 & 98.5 & 98.7 & 99 & 98.9 & 98.9 & 76.5 \\
\hline $\begin{array}{c}\text { (11) JF690921 } \\
\text { Mal012/11 }\end{array}$ & 96.1 & 95.7 & 95.7 & 93.5 & 98.2 & 99.1 & 99.5 & 99.5 & 99.5 & 98.7 & & 99.5 & 99.5 & 99.6 & 98 & 98.1 & 98 & 97.9 & 98.3 & 98.1 & 98.1 & 76.4 \\
\hline $\begin{array}{l}\text { (12) JF690922 } \\
\text { Mal013/11 }\end{array}$ & 96.1 & 95.7 & 95.7 & 93.5 & 98.2 & 99.1 & 99.5 & 99.5 & 99.5 & 98.7 & 100 & & 99.7 & 99.6 & 98.1 & 98.3 & 98 & 98 & 98.4 & 98.2 & 98.3 & 76.4 \\
\hline $\begin{array}{l}\text { (13) JF690923 } \\
\text { Mal001/11 } \\
\end{array}$ & 96.5 & 96.1 & 96.1 & 94 & 98.7 & 99.5 & 99.1 & 100 & 99.1 & 99.1 & 99.5 & 99.5 & & 99.6 & 98.3 & 98.4 & 98.3 & 98.2 & 98.5 & 98.5 & 98.4 & 76.4 \\
\hline $\begin{array}{l}\text { (14) JF690911 } \\
\text { Mal002/11 }\end{array}$ & 96.1 & 95.7 & 95.7 & 93.5 & 98.2 & 99.1 & 99.5 & 99.5 & 99.5 & 98.7 & 100 & 100 & 99.5 & & 98 & 98.1 & 97.9 & 97.9 & 98.3 & 98.1 & 98.1 & 76.3 \\
\hline (15) AY682992 PCV2b & 100 & 98.7 & 98.7 & 96.5 & 97.4 & 96.5 & 96.1 & 96.5 & 95.7 & 97.4 & 96.1 & 96.1 & 96.5 & 96.1 & & 99.5 & 98.8 & 99.2 & 99.6 & 99.3 & 99.3 & 76 \\
\hline (16) EU418627 PCV2b & 100 & 98.7 & 98.7 & 96.5 & 97.4 & 96.5 & 96.1 & 96.5 & 95.7 & 97.4 & 96.1 & 96.1 & 96.5 & 96.1 & 100 & & 98.8 & 99.3 & 99.7 & 99.3 & 99.3 & 76.1 \\
\hline (17) FJ905469 PCV2b & 98.7 & 97.4 & 97.4 & 95.2 & 96.9 & 97 & 96.5 & 97 & 96.1 & 96.9 & 96.5 & 96.5 & 97 & 96.5 & 98.7 & 98.7 & & 98.5 & 98.9 & 99 & 99 & 76.1 \\
\hline (18) FJ905470 PCV2b & 99.1 & 97.8 & 97.8 & 95.7 & 96.9 & 96.1 & 95.7 & 96.1 & 95.2 & 96.9 & 95.7 & 95.7 & 96.1 & 95.7 & 99.1 & 99.1 & 97.8 & & 99.4 & 99.2 & 99 & 75.9 \\
\hline $\begin{array}{l}\text { (19) GU247989 } \\
\text { PCV2b }\end{array}$ & 99.5 & 98.2 & 98.2 & 96.1 & 96.9 & 96.1 & 95.7 & 96.1 & 95.2 & 96.9 & 95.7 & 95.7 & 96.1 & 95.7 & 99.5 & 99.5 & 98.2 & 98.7 & & 99.4 & 99.4 & 76.1 \\
\hline $\begin{array}{l}\text { (20) HQ831530 } \\
\text { PCV2b }\end{array}$ & 100 & 98.7 & 98.7 & 96.5 & 97.4 & 96.5 & 96.1 & 96.5 & 95.7 & 97.4 & 96.1 & 96.1 & 96.4 & 96.1 & 100 & 100 & 98.7 & 99.1 & 99.5 & & 99.3 & 76.2 \\
\hline $\begin{array}{l}\text { (21) HQ831532 } \\
\text { PCV2b }\end{array}$ & 99.5 & 98.5 & 98.2 & 96.1 & 97.8 & 97 & 96.5 & 97 & 96.1 & 97.8 & 96.5 & 96.5 & 97.1 & 96.5 & 99.5 & 99.5 & 99.1 & 98.7 & 99.1 & 99.5 & & 76.4 \\
\hline (22) U49186 PCV1 & 67.6 & 66.9 & 67.7 & 66.9 & 67.3 & 66.8 & 66.8 & 65.1 & 68 & 68.5 & 67.3 & 67.3 & 67.7 & 67.3 & 67.6 & 67.6 & 67.2 & 67.2 & 67.2 & 67.6 & 67.6 & \\
\hline
\end{tabular}

PCV2 isolates found in Malaysia were compared with other PCV2b isolates and PCV1. Sequence identity scores for the other PCVs are not shown. The upper right portion is the sequence identity scores of the nucleotide alignment of the whole genome of PCV's; the lower portion is the amino acid sequence identity scores for the capsid protein (ORF2) of PCV2b. The highest nucleotide similarity scores for the Malaysian isolates are shown in bold.

This study showed that $88 \%$ of the farms $(37$ out of 42 farms) were positive for PCV2b which confirms that $\mathrm{PCV} 2$ is present in Malaysia. Currently, there are no regulations for the screening of PCV2 or other porcine diseases for imported pigs into the country. Based on statistics provided by the Department of Veterinary Services (DVS), Malaysia, there are some evidence that breeders and swine products are imported from Australia, Canada, Netherlands, America, Vietnam and other countries. Although the present study and statistics available suggests that there may be a link between imports of pig products, however, no definitive conclusions can be made as data on the countries of import from the farms in this study are not available for analysis.

The samples from this study were collected in light of the PCV2 occurrences in Malaysia in which a high number of clinical symptoms were observed in many farms. Taking into account the possibility of virus spread through animal migration and commercial trading, it is expected that viruses in the commercial swine breeds would have multiple genetic signatures. Therefore, 


$\begin{array}{ll}\text { AY484407 } & \text { PCV2b } \\ \text { JF690912 } & \text { Mal003/11 } \\ \text { JF690913 } & \text { Mal004/11 } \\ \text { JF690914 } & \text { Mal005/11 } \\ \text { JF690915 } & \text { Mal006/11 } \\ \text { JF690916 } & \text { Mal007/11 } \\ \text { JF690917 } & \text { Mal008/11 } \\ \text { JF690918 } & \text { Mal009/11 } \\ \text { JF690919 } & \text { Mal010/11 } \\ \text { JF690920 } & \text { Mal011/11 } \\ \text { JF690921 } & \text { Mal012/11 } \\ \text { JF690922 } & \text { Mal013/11 } \\ \text { JF690923 } & \text { Mal001/11 } \\ \text { JF690911 } & \text { Mal002/11 } \\ \text { AY682992 } & \text { PCV2b } \\ \text { EU418627 } & \text { PCV2b } \\ \text { FJ905469 } & \text { PCV2b } \\ \text { FJ905470 } & \text { PCV2b } \\ \text { GU247989 } & \text { PCV2b } \\ \text { HQ831530 } & \text { PCV2b } \\ \text { HQ831532 } & \text { PCV2b } \\ \text { U49186 } & \text { PCV1 } \\ & \\ \text { AY484407 } & \text { PCV2b } \\ \text { JF690912 } & \text { Mal003/11 } \\ \text { JF690913 } & \text { Mal004/11 } \\ \text { JF690914 } & \text { Mal005/11 } \\ \text { JF690915 } & \text { Mal006/11 } \\ \text { JF690916 } & \text { Mal007/11 } \\ \text { JF690917 } & \text { Mal008/11 } \\ \text { JF690918 } & \text { Mal009/11 } \\ \text { JF690919 } & \text { Mal010/11 } \\ \text { JF690920 } & \text { Mal011/11 } \\ \text { JF690921 } & \text { Mal012/11 } \\ \text { JF690922 } & \text { Mal013/11 } \\ \text { JF690923 } & \text { Mal001/11 } \\ \text { JF690911 } & \text { Mal002/11 } \\ \text { AY682992 } & \text { PCV2b } \\ \text { EU418627 } & \text { PCV2b } \\ \text { FJ905469 } & \text { PCV2b } \\ \text { FJ905470 } & \text { PCV2b } \\ \text { GU247989 } & \text { PCV2b } \\ \text { HQ831530 } & \text { PCV2b } \\ \text { H4831532 } & \text { PCV2b } \\ \text { U486 PCV1 } \\ \end{array}$

AY484407 PCV2b

JF690912 Mal003/11

JF690913 Mal004/1

JF690914 Mal005/1

JF690915 Mal006/1

JF690916 Mal007/11

JF690917 Mal008/11

JF690918 Mal009/11

JF690919 Mal010/1

JF690920 Mal011/1

JF690921 Mal012/1

JF690922 Mal013/1

JF690923 Mal001/11

JF690911 Mal002/11

AY682992 PCV2b

EU418627 PCV2b

FJ905469 PCV2b

FJ905470 PCV2b

GU247989 PCV2b

HQ831530 PCV2b

$\mathrm{HO} 831532$ PCV2b

U49186 PCV1

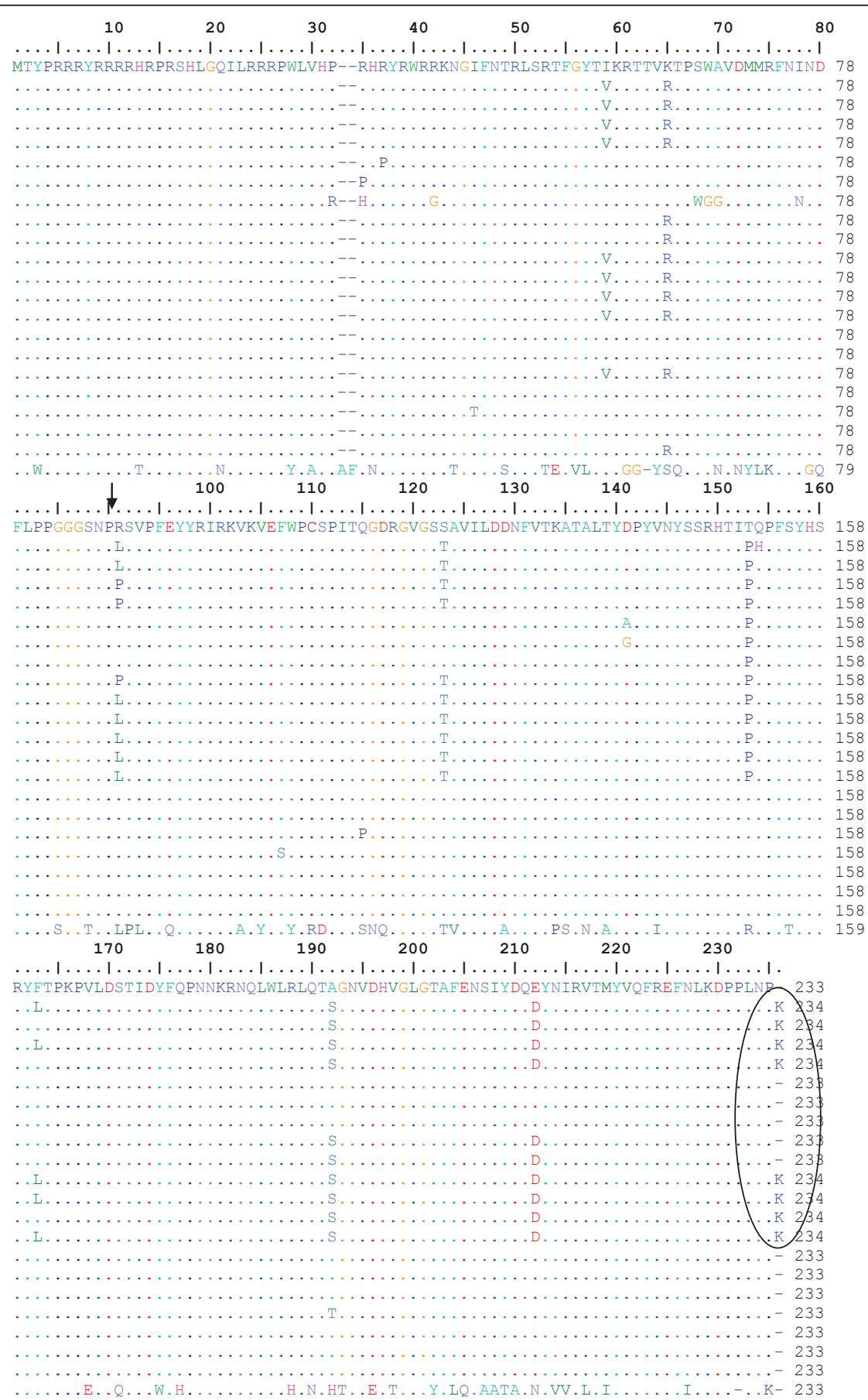

Figure 2 Amino acid sequence alignment of the putative capsid protein (ORF2) of the PCV2b cluster from this study. Deletions are indicated by hyphens. Identical sequences are doted. The arrow points at position 88-89. The circled portion denotes the mutations at the stop codon of the putative capsid protein resulting in a lysine $(K)$ residue elongation at the $C$ terminus of the ORF2 [26,28].

understanding the genetic characteristics and diversity of viruses provides new information to guide and prioritize decisions for the control of disease in livestock including the implementation of effective vaccination strategies and good biosecurity programs for the swine industry.
All animals are susceptible to a wide range of diseases that may affect its productivity. Among solutions required to minimize the risk of disease spread, strengthening the biosecurity and husbandry practices in a farm is of utmost importance. PCVs are highly 


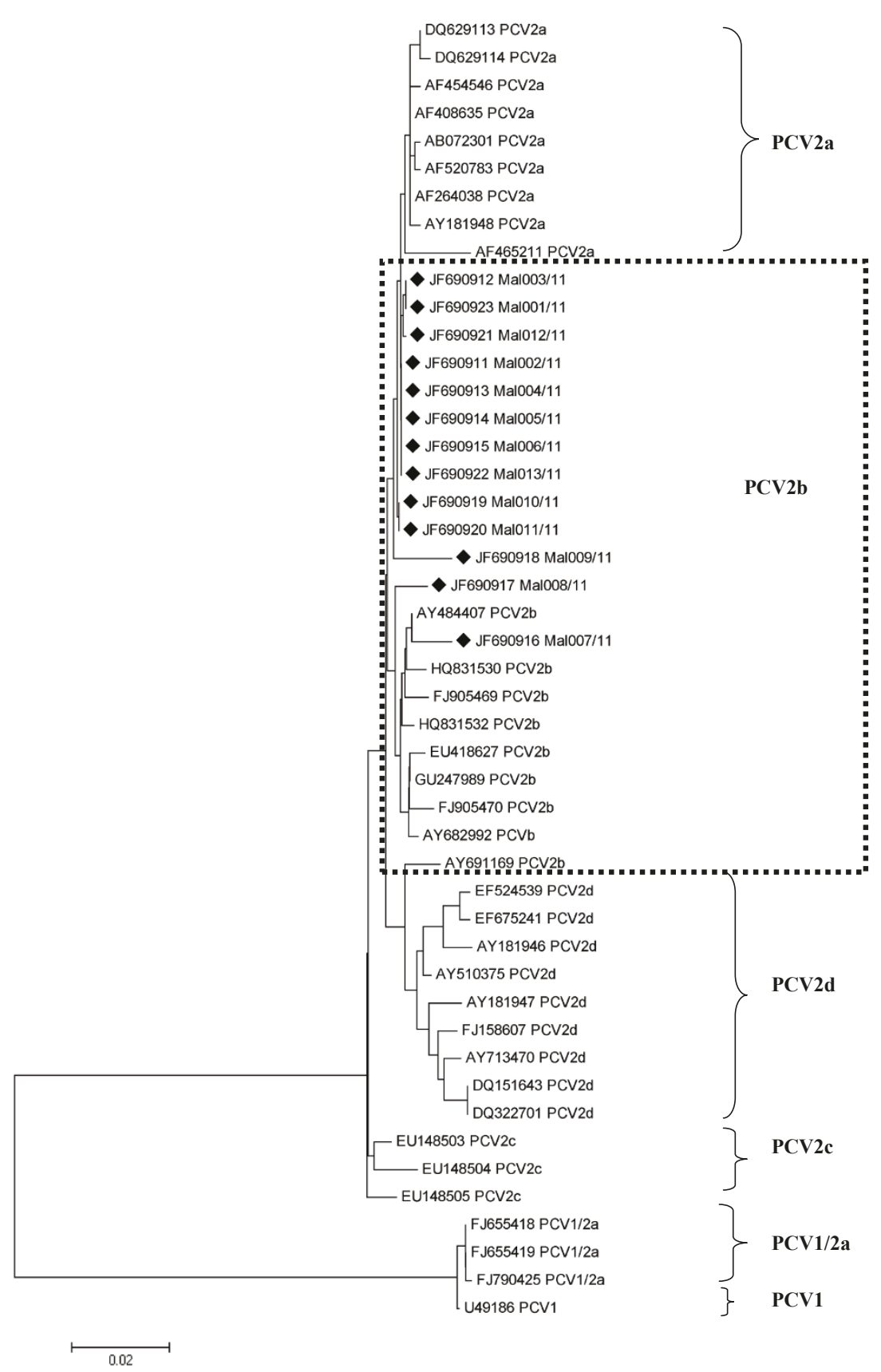

Figure 3 Phylogenetic analysis of the whole genome of the PCV2 isolates from this study with other sequences from Genbank. The sequences used to build this tree are cited in Table 1. The phylogenetic tree was constructed using the Neighbour-Joining Method and the image was reduced to 50\%. Isolates derived from this study are indicated by the rotated black square. The evolutionary distances were computed using the Maximum Composite Likelihood method. Analyses were conducted using Mega 5.

resistant to inactivation by common detergents and disinfectants. This makes decontamination of infected premises difficult, if not impossible. But combining accurate diagnosis, removal of diseased animals from farms, routine vaccination programs and a good husbandry practice could be an excellent measure for controlling losses attributed to PCV2 infections.
Each production system requires suitable biosecurity measures and the key to an enhanced biosecurity lies in the perception of biosecurity by the stakeholders in the pig farming industry for a meaningful change to take place.

In the past, a centralized pig farming has been suggested by the authorities to control pollution, safeguard 
these food animals that are meant for human consumption, improve sanitary condition, minimize environmental problems and organize the production of pigs but unfortunately, the centralized pig farming did not materialize. Perhaps, it is time that the local authorities review these measures to improve livestock production systems and to reduce the risk of disease agents.

\section{Conclusion}

Publication of whole genome sequences allows researchers to trace the presence and the spread of economically important viruses, determine their genetic distribution and assist in making priority decisions for good control programs. The findings of this study suggests that routine screening would be helpful to monitor the status of PCV2 and subsequently its control by implementing a good vaccination program and other measures such as education to the pig farmers on the consequences of PCVAD becoming an endemic disease in the country. More studies need to be done to establish the function of the mutations present in the group 1 (PCV2b) found in Malaysia before any conclusions can be made with regards to its relationship to its pathogenicity.

In conclusion, the 2.2 billion ringgit swine industry in Malaysia is an economic asset to the country's resources. Therefore, all appropriate measures should be taken to manage it well.

\section{Methods}

\section{Sampling and Screening of PCV1 and PCV2 by PCR}

Organ samples consisting of lymph nodes, kidney, liver, lungs and other specimens such as fecal samples were collected from 42 pig farms in Malaysia from animals displaying classic PCVAD clinical signs. The states included in this study were Penang, Perak, Selangor, Melaka, Johor and Sarawak. The pooled organ samples were subjected to nucleic acid extraction by using Trizol
LS reagent according to the standard manufacturer's protocol. Nested multiplex PCR with modifications from a method previously described [39] was established. The primer sets for the first step and nested step are listed in Table 3. Both the PCR mixtures consisted of $2.5 \mu \mathrm{l}$ of 10X PCR buffer, $1.5 \mu \mathrm{l} 25 \mathrm{mM} \mathrm{MgCl}_{2}, 0.5 \mu \mathrm{l} 10 \mathrm{mM}$ dNTPs, and $0.5 \mu \mathrm{l}$ of $5 \mathrm{U}$ Taq Polymerase, DNA template, the respective primer sets and PCR grade water to make up the final volume of $50 \mu \mathrm{l}$ per reaction. The PCR tubes were subjected to PCR amplification in a thermocycler (MyCycler"TM, Bio-Rad). The DNA fragment sizes were determined via agarose gel electrophoresis. This multiplex PCR is able to distinguish PCV1 and PCV2 (Figure 4).

All pigs were humanely slaughtered for sample collection under the supervision of veterinarians from the Faculty of Veterinary Medicine, UPM. There was no experimental research done on the pigs.

\section{PCR amplification of the complete genome of PCV2}

A published primer was used for amplifying the whole genome of PCV2. The primer sets were able to amplify two overlapping fragments that represent the entire genome of PCV2. The first set of primers, CV1 and CV2, amplifies a 989-bp fragment, and the second set of primers, CV3 and CV4, amplifies a 1,092 bp fragment (Table 3). The PCR amplification of the complete genome of PCV2 was established with modifications from the method as described by Fenaux M et al. 2000 (Figure 5) $[10,23]$.

\section{Nucleotide sequencing, sequencing analysis and construction of phylogenetic tree}

The PCR products of the expected sizes were purified using the PCR clean-up gel extraction kit according to the manufacturer's protocol with slight modifications (Macherey-Nagel, Germany). Sequencing of the

Table 3 Primer pairs used for screening the suspected cases and for sequencing the complete genome of PCV2

\begin{tabular}{|c|c|c|c|c|c|}
\hline Primer & Sequence $\left(5^{\prime}-3^{\prime}\right)$ & Size of PCR Product (bp) & Nucleotide position & PCR step & Reference \\
\hline PCV-1 forward & CTC GGC AGC GTC AGT GAA AA & 570 & 800-819 & First step (xPCR) & {$[39]$} \\
\hline PCV-1 reverse & AAA TTA CGG GCC CAC TGG CT & & 1350-1369 & & \\
\hline PCV-2 forward & CGG ATA TTG TAG TCC TGG TCG & 481 & 1095-1115 & & \\
\hline PCV-2 reverse & ACT GTC AAG GCT ACC ACA GTC A & & $1549-1570$ & & \\
\hline PCV-1 forward & CCT TCC GAG GAG GAG AAA AAC & 491 & $879-900$ & Nested PCR (nPCR) & \\
\hline PCV-1 reverse & AAA TTA CGG GCC CAC TGG CT & & 1350-1369 & & \\
\hline PCV-2 forward & GGT TTG GGT GTG AAG TAA CGG G & 329 & $1242-1263$ & & \\
\hline PCV-2 reverse & ACT GTC AAG GCT ACC ACA GTC A & & $1549-1570$ & & \\
\hline CV1-forward & AGG GCT GTG GCC TाT GTT AC & 989 & $1336-1355$ & Sequencing & {$[10,23]$} \\
\hline CV2-reverse & TCT TCC AAT CAC GCT TCT GC & & $536-556$ & & \\
\hline CV3-forward & TGG TGA CCG TTG CAG AGC AG & 1093 & $453-471$ & & \\
\hline CV4-reverse & TGG GCG GTG GAC ATG ATG AG & & $1525-1544$ & & \\
\hline
\end{tabular}




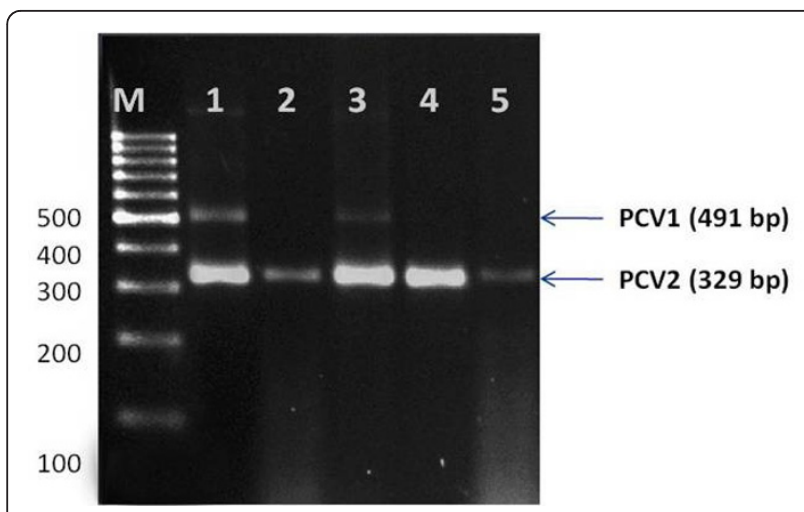

Figure $4 \mathrm{Gel}$ electrophoresis image of the multiplex PCR used for the screening of PCV1 and PCV2. The amplicon size for PCV1 is $491 \mathrm{bp}$ and the amplicon size for PCV2 is $329 \mathrm{bp}$ [39].

complete genome of PCV2 was done in a commercial sequencing facility using the BigDye Terminator v3.1 cycle sequencing kit. After sequencing, a Basic Local Alignment Search Tool (BLAST) was performed with the derived DNA sequence as a preliminary measure to confirm that all samples were true PCV2 when compared with other sequences deposited in Genbank. The sequence editing and assembly were done by using CLC Workbench. Multiple sequence alignments were done by using ClustalW. The phylogenetic tree was constructed by using the distance-based neighbor joining method and generated by using Mega 5 (Biodesign

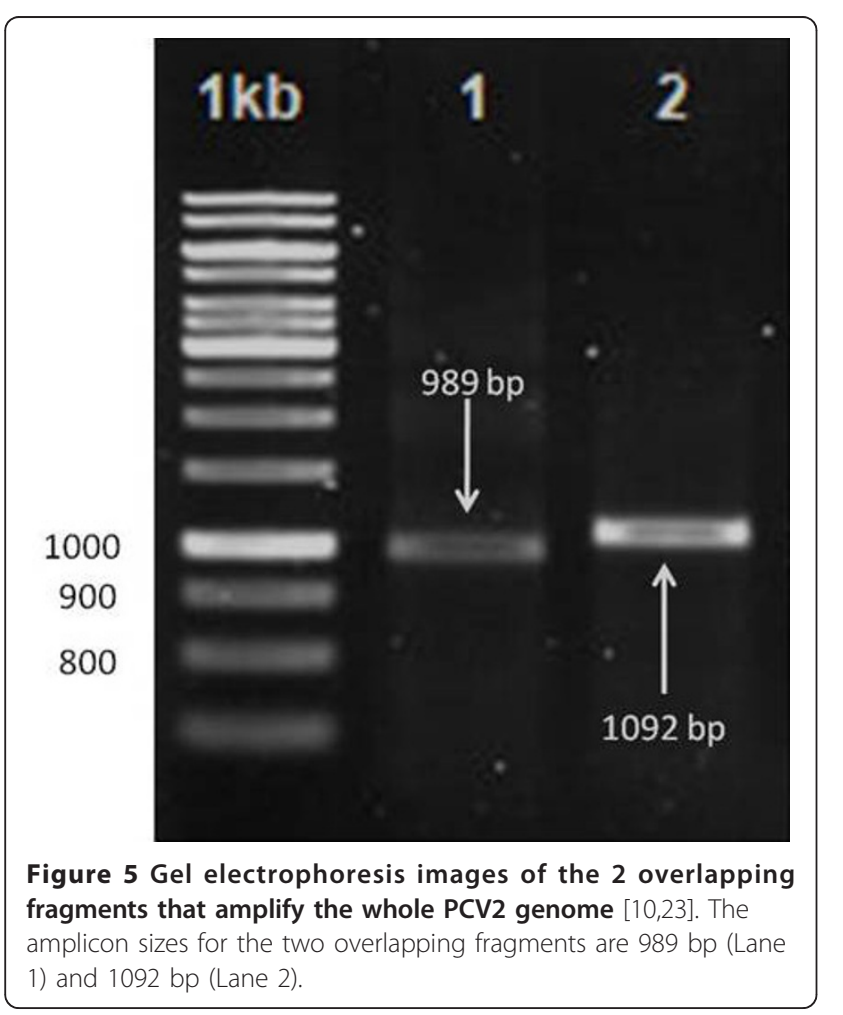

Institute, Tempe, Arizona) and evaluated using the bootstrapping method calculated on 1000 repeats of the alignment (Data not shown). The sequence identity matrix data was generated with BioEdit Sequence Alignment Editor version 7.0.5.2 (Tom Hall, US). Sequences used for constructing the phylogenetic tree are listed in Table 1. PCV1 sequences were included in the tree as an out group, whilst PCV1/2a sequences were included to investigate whether similar recombinant events of the ORF1 and ORF2 of PCV2 are found in Malaysia. Sequences for PCV2e could not be analyzed as the sequence was not available in Genbank.

\section{Nucleotide sequence accession numbers}

The complete genomic sequences of the 13 PCV2 isolates reported in this paper were deposited with the GenBank database under accession numbers JF690911, JF690912, JF690913, JF690914, JF690915, JF690916, JF690917, JF690918, JF690919, JF690920, JF690921, JF690922 and JF690923. These sequences are downloadable from Entrez Pop Set data as a group of sequences.

\section{Acknowledgements}

All samples used in this study were provided by Vet Food Agro Diagnostic (M) Sdn. Bhd.

\section{Author details}

${ }^{1}$ Department of Clinical Studies, Faculty of Veterinary Medicine, Universiti Putra Malaysia, 43400 UPM, Serdang, Selangor, Malaysia. ${ }^{2}$ Department of Biotechnology, Faculty of Biotechnology, Universiti Putra Malaysia, 43400 UPM, Serdang, Selangor, Malaysia. ${ }^{3}$ Asia-Pacific Special Nutrients Sdn. Bhd, Lot 18B, Jalan 241, Section 51A, 46100 Petaling Jaya, Selangor, Malaysia. ${ }^{4}$ Rhone Ma Malaysia (M) Sdn Bhd, Lot 18B, Jalan 241, Section 51A, 46100, Petaling Jaya, Selangor, Malaysia.

\section{Authors' contributions}

SJ designed and conceived the research, participated in the conceptual aspect of the work, performed the experiments and wrote the manuscript. OPT, PLY, TDY, CPY and LBK provided consultation and coordination. All authors read and approved the final manuscript.

\section{Competing interests}

The authors declare that they have no competing interests.

Received: 17 May 2011 Accepted: 13 September 2011

Published: 13 September 2011

\section{References}

1. Allan GM, McNeilly F, Kennedy S, Daft B, Clarke EG, Ellis JA: Isolation of porcine circovirus-like viruses from pigs with a wasting disease in the USA and Europe. J Vet Diagn Invest 1998, 10:3-10.

2. Allan GM, Phenix KV, Todd D, McNulty MS: Some biological and physicochemical properties of porcine circovirus. Zentralbl Veterinarmed B 1994, 41:17-26.

3. Allan GM, Ellis JA: Porcine circovirus: a review. J Vet Diagnostic Invest 2000, 12:3-14.

4. Chae C: Postweaning multisystemic wasting syndrome: a review of aetiology, diagnosis and pathology. Vet J 2004, 168:41-9.

5. de Boisseson C, Beven V, Bigarre L, Thiery R, Rose N, Eveno E: Molecular characterization of Porcine circovirus type 2 isolates from post-weaning multisystemic wasting syndrome-affected and non-affected pigs. J Gen Virol 2004, 85:293-304. 
6. Grau-Roma L, Crisci E, Sibila M, Lopez-Soria S, Nofrarias M, Cortey M: A proposal on porcine circovirus type 2 (PCV2) genotype definitions and their relation with postweaning multisystemic wasting syndrome (PMWS) occurrence. Vet Microbiol 2008, 128:23-35.

7. Tischer I, Gelderblom H, Vettermann W, Koch MA: A very small porcine virus with circular single-stranded DNA. Nature 1982, 295:64-6.

8. Tischer I, Mields W, Wolff D, Vagt M, Griem W: Studies on epidemiology and pathogenicity of porcine circovirus. Arch Virol 1986, 91:271-6.

9. Tischer I, Rasch R, Tochtermann G: Characterization of papovavirus-and picornavirus-like particles in permanent pig kidney cell lines. Zentralb/ Bakteriol 1974, 226:153-167.

10. Fenaux M, Halbur PG, Gill M, Toth TE, Meng XJ: Genetic characterization of type 2 porcine circovirus (PCV-2) from pigs with postweaning multisystemic wasting syndrome in different geographic regions of North America and development of a differential PCR-restriction fragment length polymorphism assay to detect and differentiate between infections with PCV-1 and PCV-2. J Clin Microbiol 2000, 38:2494-503.

11. Cadhla Firth, Charston MA, Duffy S, Shapiro B, Holmes EC: Insights into the evolutionary history of an emerging livestock pathogen: Porcine circovirus 2. J Virology 2009, 83:12813-12821.

12. Harding JC: History of Porcine Circoviral Disease (PCVD) and Current Western Canadian Situation.[http://www.banffpork.ca/proc/2007pdf/027\% 20-\%20Harding.pdf].

13. Gagnon CA, Music N, Fontaine G, Tremblay D, Harel J: Emergence of a new type of porcine circovirus in swine (PCV): A type 1 and type 2 PCV recombinant. Vet Microbiol 2010, 144:18-23.

14. Dupont K, Nielsen EO, Baekbo P, Larsen LE: Genomic analysis of PCV2 isolates from Danish archives and a current PMWS case-control study supports a shift in genotypes with time. Vet Microbiol 2008, 128:56-64.

15. Guo LJ, Lu YH, Wei YW, Huang LP, Liu CM: Porcine circovirus type 2 (PCV2); genetic variation and newly emerging genotypes in China. Virology Journal 2010, 7:273-284.

16. Jantafong Tippawan, Boonsoongnern Alongkot, Poolperm Pariwat, Urairong Kitcha, Lekcharoensuk Chalermpol, Lekcharoensuk Porntippa: Genetic characterization of porcine circovirus type 2 in piglets from PMWS-affected and -negative farms in Thailand. Virology Journal 2011, 8:88.

17. Mankertz A, Hillenbrand B: Analysis of transcription of porcine circovirus type 1. J Gen Virol 2002, 83:2743-51.

18. Ellis J, Krakowka S, Lairmore M, Haines D, Bratanich A, Clark E: Reproduction of lesions of postweaning multisystemic wasting syndrome in gnotobiotic piglets. J Vet Diagn Invest 1999, 11:3-14.

19. Manokaran Gayathri, Lin Yueh-Nuo, Soh Moi-Lien, Lim Ai-Sim Elizabeth, Tan Boon-Huan: Detection of porcine circovirus type 2 in pigs imported from Indonesia. Veterinary Microbiology 2008, 132:165-170.

20. Harding JC, E: Recognizing and diagnosing post-weaning multisystemic wasting syndrome (PMWS). J Swine Health and Production 1998, 5:201-3.

21. Harding JC: The clinical expression and emergence of porcine circovirus 2. Vet Microbiol 2004, 98:131-5.

22. Hesse R, Kerrigan M, Rowland RR: Evidence for recombination between PCV2a and PCV2b in the field. Virus Res 2008, 132:201-7.

23. Horlen KP, Schneider P, Anderson J, Nietfeld JC: A cluster of farms experiencing severe porcine circovirus associated disease; Clinical features and association with the PCV2b genotype. J Swine Health and Production 2007, 15:270-278.

24. Fenaux M, Opriessnig T, Halbur PG, Elvinger F, Meng XJ: Two amino acid mutations in the capsid protein of type 2 porcine circovirus (PCV2) enhanced PCV2 replication in vitro and attenuated the virus in vivo. J Virology 2004, 78:13440-6.

25. Ellis JA, Bratanich A, Clark EG, Allan G, Meehan B, Haines DM: Coinfection by porcine circoviruses and porcine parvovirus in pigs with naturally acquired postweaning multisystemic wasting syndrome. J Vet Diagn Invest 2000, 12:21-7.

26. Olvera A, Cortey M, Segales J: Molecular evolution of porcine circovirus type 2 genomes: phylogeny and clonality. Virology 2007, 357:175-85.

27. Segales J, Olvera A, Grau-Roma L, Charreyre C, Nauwynck H, Larsen L: PCV2 genotype definition and nomenclature. Vet Rec 2008, 162:867-8.

28. Knell S, Willems H, Hertrampf B, Reiner G: Comparative genetic characterization of porcine circovirus type 2 samples from German wild boar populations. Vet Microbiol 2005, 109:169-177.
29. Larochelle R, Magar R, D'Allaire S: Genetic characterization and phylogenetic analysis of porcine circovirus type 2 (PCV2) strains from cases presenting various clinical conditions. Virus Res 2002, 90:101-12.

30. Lekcharoensuk P, Morozov I, Paul PS, Thangthumniyom N, Wajjawalku W, Meng XJ: Epitope mapping of the major capsid protein of type 2 porcine circovirus (PCV2) by using chimeric PCV1 and PCV2. J Virol 2004, 78:8135-45.

31. Mankertz A, Caliskan R, Hattermann K, Hillenbrand B, Kurzendoerfer P, Mueller B: Molecular biology of porcine circovirus: analyses of gene expression and viral replication. Vet Microbiol 2004, 98:81-8.

32. Nawagitgul P, Morozov I, Bolin SR, Harms PA, Sorden SD, Paul PS: Open reading frame 2 of porcine circovirus type 2 encodes a major capsid protein. J Gen Virol 2000, 81:2281-2287.

33. Ooi PT, Choo PY, Hii DO, Shahirudin S, Seetha J, Lim BK: Identification of porcine circovirus type 2 from pigs with postweaning multisystemic wasting syndrome in Malaysia. Proceedings of the 19th Veterinary Malaysia Association Scientific Congress 109-111.

34. Dong-Jun A, In-Soon R, Dae-Sub S, Choi-Kyu P, Bong-Kyun P: Phylogenetic characterization of porcine circovirus type 2 in PMWS and PDNS Korean pigs between 1999 and 2006. Virus Research 2007, 129:115-122.

35. Ellis J, Clark E, Haines D, West K, Krakowka S, Kennedy S: Porcine circovirus2 and concurrent infections in the field. Vet Microbiol 2004, 98:159-63.

36. Segales J, Sitjar M, Domingo M, Dee S, Del Pozo M, Noval R: First report of post-weaning multisystemic wasting syndrome in pigs in Spain. Vet Rec 1997, 141:600-1.

37. Segales J, Calsamiglia M, Olvera A, Sibila M, Badiella L, Domingo M: Quantification of porcine circovirus type 2 (PCV2) DNA in serum and tonsillar, nasal, tracheo-bronchial, urinary and faecal swabs of pigs with and without postweaning multisystemic wasting syndrome (PMWS). Vet Microbiol 2005, 111:223-9.

38. Mankertz A, Domingo M, Folch JM, LeCann P, Jestin A, Segales J: Characterization of PCV-2 isolates from Spain, Germany and France. Virus Res 2000, 66:65-77

39. Kim J, Chae C: Multiplex nested PCR compared with in situ hybridization for the differentiation of porcine circoviruses and porcine parvovirus from pigs with postweaning multisystemic wasting syndrome. Canadian Journal of Vet Res 2003, 67:133-137.

doi:10.1186/1743-422X-8-437

Cite this article as: Jaganathan et al:: Genetic characterization of Porcine Circovirus 2 found in Malaysia. Virology Journal 2011 8:437.

\section{Submit your next manuscript to BioMed Central and take full advantage of:}

- Convenient online submission

- Thorough peer review

- No space constraints or color figure charges

- Immediate publication on acceptance

- Inclusion in PubMed, CAS, Scopus and Google Scholar

- Research which is freely available for redistribution

Submit your manuscript at www.biomedcentral.com/submit
C Biomed Central 